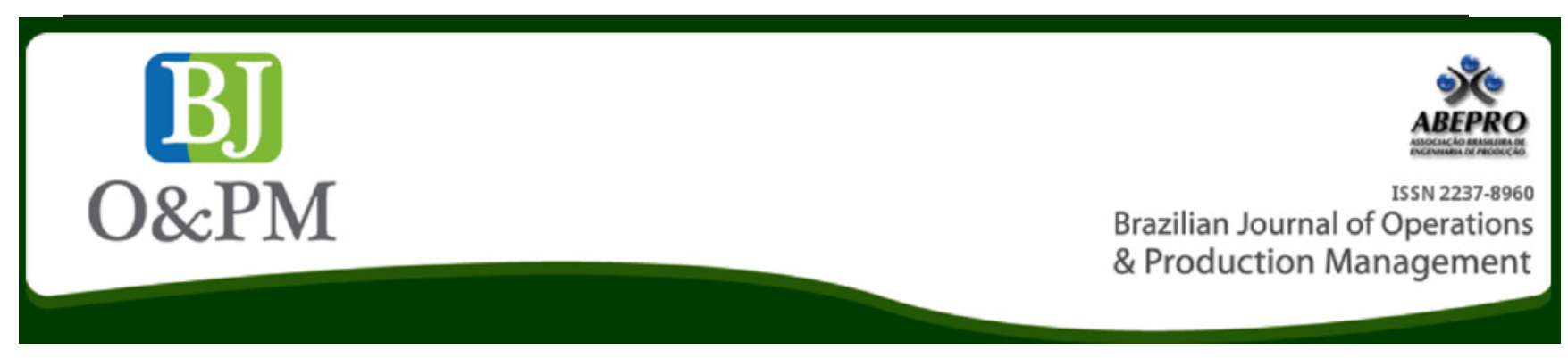

\title{
LEAN \& HEALTHCARE ORGANIZATIONS - A SYSTEMATIC LITERATURE REVIEW WITH BIBLIOMETRIC ANALYSIS ON APPLICATION OF LEAN HEALTHCARE IN BRAZIL
}

William de Paula Ferreira ; Adriano Maniçoba da Silva ${ }^{a}$; Wilson Yoshio Tanakaa; Eugênio de Felice Zampinia

${ }^{\text {a }}$ Federal Institute of Education, Science and Technology of Sao Paulo (IFSP) - Suzano, SP, Brazil

\begin{abstract}
Despite having its roots in the Japanese automotive industry, Lean philosophy has been successfully applied in many companies of different sectors. In recent years several studies have been done regarding the potential of this managerial technology that may transform the healthcare organizations. The objective of this theoretical research paper is to conduct a Systematic Literature Review (SLR) with bibliometric analysis on application of Lean healthcare in Brazil. The aim is to understand the advancement of this research field in Brazil, investigating how Lean thinking has been put into practice and how this innovation has helped those companies to deliver more value to its customers. Peer reviewed articles were searched in 9 data sources. At first, a total of 5,473 articles were identified, which were reduced to 2,983 after Endnote software duplicate reference analysis. 789 articles were screened, after reviewing the adherence to the topic. Resulting in a sample of only 9 articles, after all inclusion criteria were match. The results suggest that Lean thinking has been applied successfully in many healthcare organizations. However, the research field in Brazil is quite new, having a great potential to increase.
\end{abstract}

Key words: Lean thinking; Lean healthcare; Brazil; Toyota. 


\section{INTRODUCTION}

Lean philosophy is based on Toyota Production System (TPSwhich aim to increase value-added work by eliminating wastes, improving overall process efficiency (Holweg, 2007). Despite having appeared in a Japanese automobile industry, the fundamental ideas of the Lean management had a global context and can be applied to any kind of business settings (Womack et al., 1990).

Many authors support the strong relationship existence between Lean and innovation models. Considering innovation as a key capability of Lean implementation and development (Veiga et al., 2011).

To Eroglu et Hofer (2011), Lean approach is specifically beneficial for the small enterprises, where profit maximization can be done in such a way that cannot be easily copied by competitors. Since it is rather based on the improvement of the way a work is carried out along with streamlining its associated resources. This reflects the robustness of such approach.

The Brazilian health system is made up of a complex network of complementary and competitive service providers and purchasers, forming a public-private mix that is financed mainly by private funds (Paim et al., 2011). In Brazil, the health market moves around $\mathrm{R} \$ 161.9$ billion or $2.74 \%$ of the Brazilian GDP. In total, they employ about 2.03 million workers and is largely made up of Micro and Small Enterprises (MSE) (FEHOESP/IBPT, 2016).

To Ferraz (1998), Brazil, as many other countries, need to implement programs for the more efficient delivery of health care services. In this sense, many papers have been published in recent years about Lean healthcare. Including others systematic literature reviews: Young et McClean (2008); Mazzocato et al. (2010); Peralta et Forcellini (2015); and Moraros et al. (2016). However, none of them gives an overview of Lean healthcare research field in Brazil. Also uses a limited number of data sources (Mazzocato et al., 2010, Peralta et Forcellini, 2015).

The objective of this paper is to cover theoretical research gap, conducting a systematic literature review with biometric analysis concerning Lean healthcare application in Brazil. The data sources SCOPUS, Web of Science, Ebsco, Scielo, Wiley, Compendex, Ermerald, ProQuest and PubMed, were used in order to understand the maturity of this research field in Brazil, how Lean thinking in healthcare organizations is working in practice and how the sectors can deliver more value by adopting Lean healthcare.

This article is structured as follows: in section 2 we have the classification of research and methodological procedures; Section 3 describes the analysis of the literature; Section 4 the results; Section 5 presents the discussion and research opportunities; and finally, in section 6 the final conclusions and considerations are exposed.

\section{METHODOLOGY}

This is a theoretical research. The objectives are exploratory and descriptive, categorized as a bibliographical study with bibliometric analysis, which use a mixed method, combining quantitative and qualitative analysis (Baumeister, 2013).

To conduct a scientifically rigorous Systematic Literature Review (SLR), we used the 8 steps guideline proposed by Okoli and Schabram (2010). The SLR was made using the following data sources: Scopus, Web of Science, EBSCO host, Scielo, Wiley, Compendex - Engineering Village, Ermerald, Proquest and Pubmed. It's Chosen due its broad scope, quality and adherence, as analyzed by Falagas et al. (2008), Baumeister (2013) and Ferenhof (2016).

Searches were carried out using the following keywords: Lean healthcare, Lean hospital, Toyota healthcare, Toyota hospital, Hospital enxuto, Saúde enxuta.

At first, peer review articles, from all dates about Lean healthcare were used as inclusion criteria to seek the articles. The duplicates articles were removed using Endnote software. Then, the titles, abstracts and key words were analyzed to check if the articles were adherent to the research topic. Further, we filter the articles by region (Brazil) and identified articles on interventions. Excel spreadsheet was used to extract and analyses the relevant data, to perform the bibliometric analysis.

\section{LITERATURE REVIEW}

Lean is derived from Toyota Production System (TPS) (Holweg, 2007). Lean philosophy is a system that creates maximum outputs with minimum input possible (Womack et Jones, 1994), which aim to increase value-added work by eliminating wastes, improving overall process efficiency.

Lean thinking has five fundamental principles: Specify Value; Value stream mapping (VSM); Flow, Pull, Perfection (Womack et Jones, 1994). Any organization wishing to implement lean manufacturing should understand the meaning of these elements and adopt them in their operations.

According to Ohno (1988), there are 7 kinds of waste that must be banished from all processes: Over Production; Inventory; Transport; Bad Quality; Operator motion; Idle Time; and Processing.

There have been numerous benefits of lean production as mentioned in the available literature. Lean approach is enriched with a number of embedded methods and tools. However, it is worth mentioning that Lean is not a mere toolkit. This is such a sophisticated system where all the elements in the system work in a holistic way to accomplish its goal. The whole at its roots focuses on supporting and encouraging people to continually improve the processes they work on. 
B Brazilian Journal of Operations \& Production Management Volume 13, Número 4, 2016, pp. 422-428

DOI: 10.14488/BJOPM.2016.v13.n4.a2
Womack et Jones (1994) have argued that Lean thinking had a global context, which can be applied to any kind of business settings. Also recommended to healthcare (Womack et al., 2005). However, due to the varieties of sectors and business models it is important to highlight that many papers came not just to just validate its theory but due to the particularity of different process in different business. The way the implementation takes place can vary dramatically and, can decisive the success or failure of the implementation. Otherwise, Lean can be misunderstood as another fashion that rapidly came and rapidly goes.

It is uncertain to say the precise date of the first application of Lean in healthcare. According to Laursen et al. (2003), Young et McClean (2008), Lean thinking emerged in operations around 1992, in service around 1996, and in the medical arena in the early 2000. One of the latest sector to import Lean (Brandão de Souza, 2009).

According to Graban (2011), Toussaint et Gerard (2010), Lean healthcare seek to increase quality of assistance, focusing on patients. The aim is identifying value for patients and banish all kinds of wastes. Minimizing the time to treatment, reduce medical errors, increase capacity, and more.

\section{RESULTS}

At first, a total of 5,473 articles were identified from 9 data sources, which were reduced to 2,983 articles after Endnote software duplicated reference analysis. After reading the title, abstract and key words of all those articles, 798 papers really talked about Lean healthcare. Further we filtered the articles by country (Brazil) and also by research methodology, excluding theoretical research papers, which resulted in a sample of only 9 articles, after that inclusion criteria were match. The Figure 1 exemplifies the procedure.

A first analysis sought to understand the evolution of the research field. As it can be seen in the Figure 2, the most papers dated and have grown over the last ten years. Concerning the country where the study was done, the 789 articles identified belongs to 44 different countries. However, $51.6 \%$ are from USA and $13.6 \%$ from UK. Only 15 papers were from Brazil, corresponding 1.9\% of total (Figure 3).

The Figure 4. Shows the key words with more occurrences among the 789 papers.

From 15 identified Brazilian articles, 6 are theoretical studies and 9 applied research. As shown in Figure 5, the papers were published mainly over the last 2 years.

Each one of the 9 papers were published in 9 different journals. The Impact (IF) of the Journals were extracted from Journal Citation Report (JCR) and Capes Sucupira platform, both presented at Table 1 .

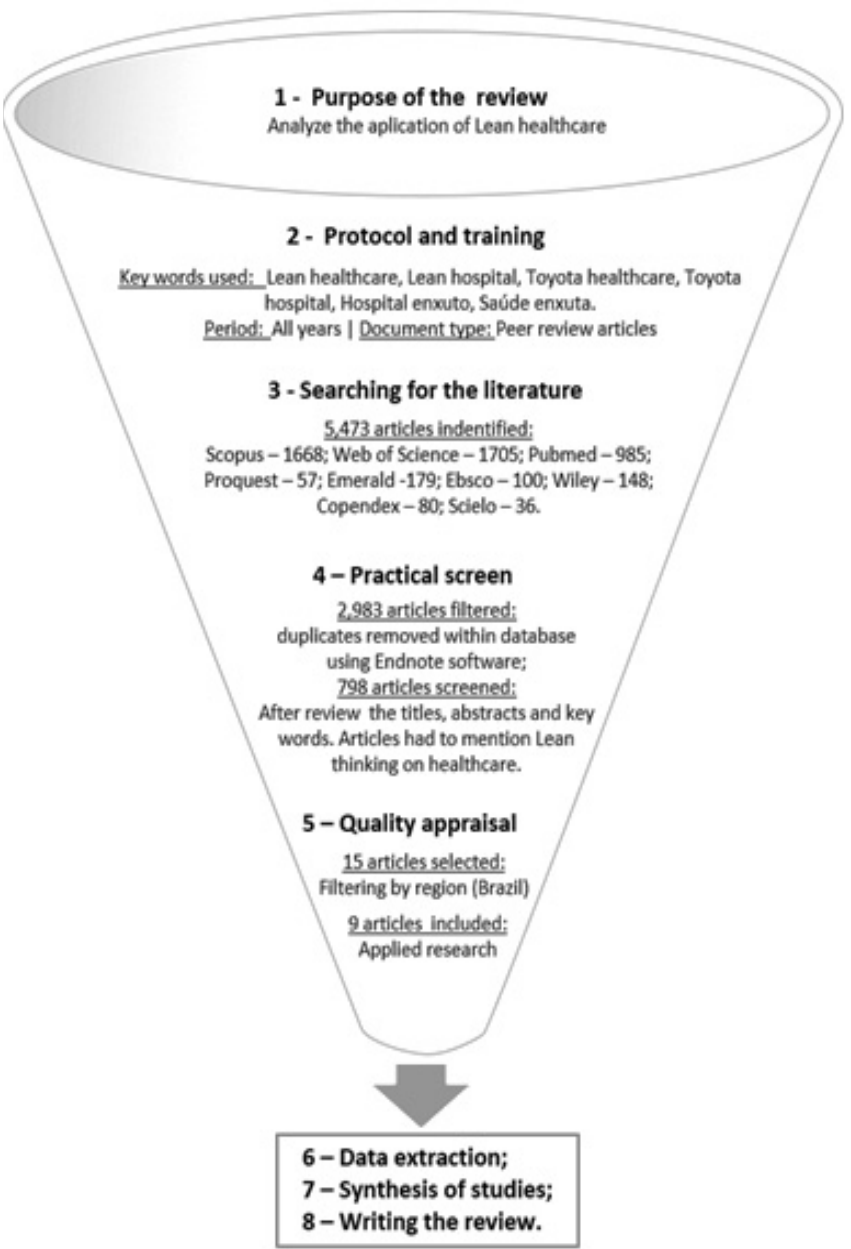

Figure 1. Systematic Literature review Source: Adapted from Okoli et Schabram (2010)

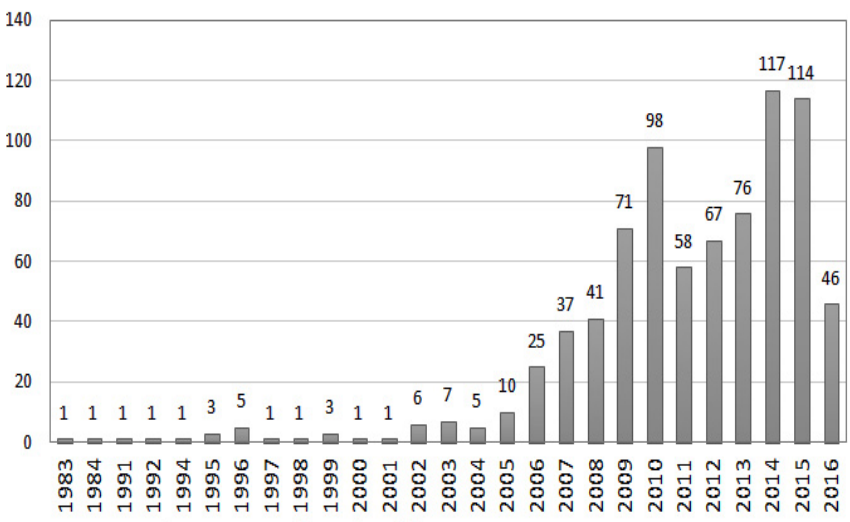

Figure 2. Number of publications per year Source: The author(s) own

Table 2 has the number of citations per article. The search was made by using the JCR and at Google Scholar platforms.

Table 3 summarizes the main contributions of the 9 articles. Highlighting the area, methods, tools utilized and outcomes. 


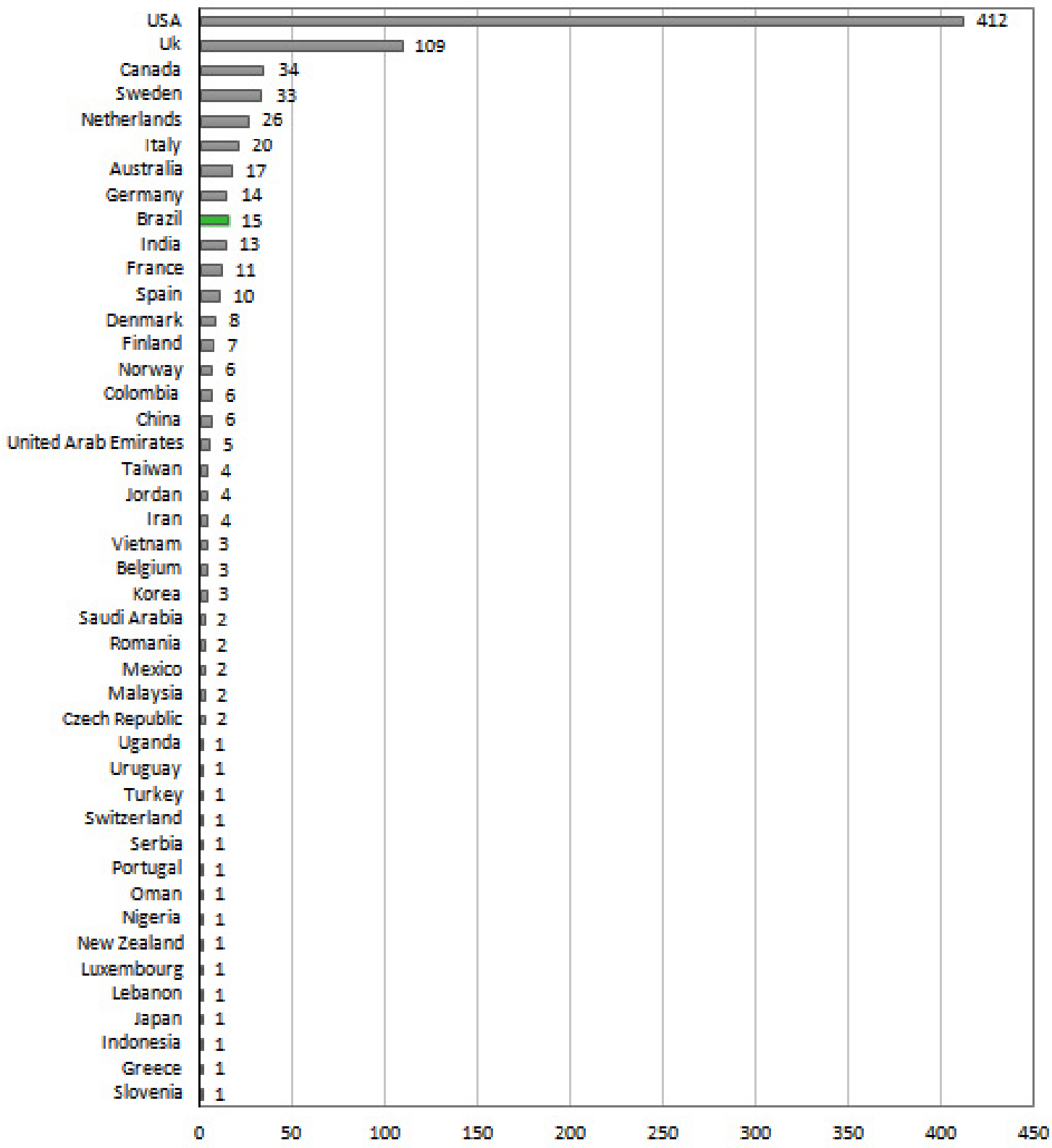

Figure 3. Number of Publications per country Source: The author(s) own

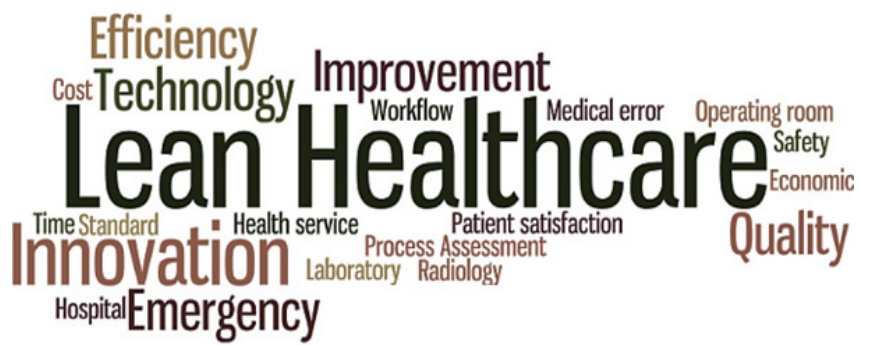

Figure 4. Word cloud of most recurrent key words Source: The author(s) own

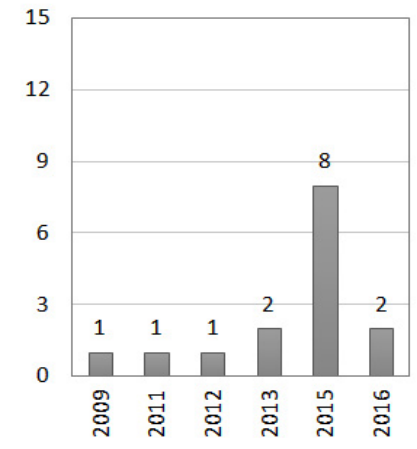

Figure 5. Publications per year (from Brazil) Source: The author(s) own 
Brazilian Journal of Operations \& Production Management Volume 13, Número 4, 2016, pp. 422-428

DOI: 10.14488/BJOPM.2016.v13.n4.a2

Table 1. Journals impact factor

\begin{tabular}{|l|c|c|}
\hline \multicolumn{1}{|c|}{ JOURNAL } & QUALIS & IF \\
\hline O Mundo da Saúde & B2 & $*$ \\
\hline Einstein (São Paulo) & B4 & $*$ \\
\hline $\begin{array}{l}\text { The International journal of health planning } \\
\text { and management }\end{array}$ & $*$ & 1.110 \\
\hline Revista Latino-Americana de Enfermagem & $*$ & 0.687 \\
\hline Quality Engineering & B1 & 0.883 \\
\hline International Journal of Lean Six Sigma & $*$ & $*$ \\
\hline $\begin{array}{l}\text { Jornal Brasileiro de Patologia e Medicina } \\
\text { Laboratorial }\end{array}$ & C & 0.085 \\
\hline Rev Bras Enferm & B3 & $*$ \\
\hline Production Planning and Control & B1 & $*$ \\
\hline
\end{tabular}

Source: The author(s) own

Table 2. Number of citations per article

\begin{tabular}{|l|c|}
\hline \multicolumn{1}{|c|}{ REFERENCE } & CITATIONS \\
\hline da Cunha et al. (2011) & 0 \\
\hline Hors et al. (2012) & 0 \\
\hline Costa et al. (2015) & 0 \\
\hline Eiro and Torres-Junior (2015) & 1 \\
\hline Godinho Filho et al. (2015) & 0 \\
\hline da Silva et al. (2015) & 0 \\
\hline Quetz et al. (2015) & 0 \\
\hline Furukawa et al. (2016) & 3 \\
\hline Henrique et al. (2016) & \\
\hline \multicolumn{2}{c|}{ Source: The author(s) own } \\
\hline
\end{tabular}

\section{DISCUSSION}

The results of this bibliometric study allowed us to verify important elements of the healthcare literature in Brazil. A systematic review of literature returned the articles published in the nine databases indicating that the number of publications has increased significantly in recent years mainly in the 2010, 2014 and 2015 periods in which the maximum amount of articles were published. This increase in the number of papers published follows the results of Peralta et Forcellini (2015), who identified similar changes in the same period of time. Based on these results we can affirm that this research field is quite new because most of papers date from the last 10 years.

The analysis also allowed us to verify the nationality of the studies, where it can be seen that the United States leads the quantity and publications with more articles published than the other countries. We also check that Brazil is on 9th position between the most prolific countries indicating a certain vocation of the country to conduct this type of study and also the opportunity to expand the number of papers. In Brazil, it can be seen that the year 2015 is the period with the highest number of publications with 8 articles.
An analysis of the most frequent keywords could highlight: improvement, innovation, quality and efficiency, as the concepts contained in the articles of Lean Healthcare. This finding reinforces the goal of Lean is to improve the efficiency of processes and also the fact that innovation is a key element in Lean (Holweg, 2007, Veiga et al., 2011). These keywords indicate that the application of Lean in Healthcare sector implies the adoption of several continuous improvement tools. In addition to this group of words, in a secondary level of frequency are the words, standard, time, patient satisfaction, surgery and surgery room, also indicating the tools used and the application.

Although Brazil appears on 9th position of the most prolific countries, it can be seen that the applied articles have little quote and only has two citations in databases. Also, only 5 have qualifications at the national level and other 5 had no impact factor available. This result reinforces the need for studies conducted in the Lean Healthcare approach using the results of studies produced nationally. This result contrasts the outcomes obtained in Peralta et Forcellini (2015), wherein the identified items have more citations with the highest were 123.

In the application reported in the articles the place that appears in most studies refer to results in the State of São Paulo (da Cunha et al., 2011, Hors et al., 2012, Eiro and Torres-Junior, 2015, da Silva et al., 2015, Furukawa et al., 2016, Henrique et al., 2016), followed by one application in the state of Ceará (Quetz et al., 2015). Referring to the application site it was noted that most studies relate to applications in hospitals, where one of the studies concerns the application in a clinical (Hors et al., 2012).

In studies that investigated hospitals, one also referred specifically to the hospital operating area, the laundry, another was one that was applied in management and scientific research, and a study conducted in internal service sector and laboratories. It appears therefore that Lean applications in healthcare sector adopted both clinical and operational dimension (Young and McClean, 2008).

It is important to note that 6 articles, from 9 analyzed, used hybrid approach, such as Lean Six Sigma. The interventions reported refers to the following techniques: Value Stream Mapping (VSM), Kaizen, continuous flow, standardizing process, PDCA, DMAIC, quality tools, development of Lean Six Sigma and PMBOK for project management, application of Total Quality models, waste reduction and lead time in administrative proceedings, redefinition of the technical work dynamics, process mapping and layout redesign. In complement to Mazzocato et al. (2010), the papers revised in this study reported significant technical applications with better indicators reached as presented in da Cunha et al. (2011) a $40 \%$ of lead time reduction. 


\section{CONCLUSION}

This paper accomplished its objective, which was to conduct a Systematic Literature Review of the application of Lean in Healthcare organizations in Brazil.

The analysis of the papers indicated several clues of the state of the literature of lean and its application in healthcare sector in Brazil. The main contribution of this article compared to other studies that conducted systematic literature review was to identify the application of Lean Healthcare in Brazil searching in several available databases.

Thus, by the analysis conducted in the previous section, the study concludes that, instead of a large increase in the number of publications in the last year, application of this topic in Brazil has a great potential to increase. Despite Brazil's 9th position in the most prolific countries, the articles were published in journals with low or no impact factor and with small rate of citations. This fact seems to be an opportunity to conduct these studies in Brazil.

The other contribution of this paper is the list of the intervention and techniques used to improve Healthcare organizations. Future studies could augment the set of databases analyzed and also do the same approach on an international perspective. As stated by (Moraros et al. (2016)) more study is needed to better investigate the real effects of lean application in Healthcare organizations.

\section{REFERENCES}

BAUMEISTER, R. F. 2013. Writing a literature review. The Portable Mentor. Springer.

BRANDAO DE SOUZA, L. 2009. Trends and approaches in lean healthcare. Leadership in health services, 22, 121-139.

COSTA, L. B., FILHO, M. G., RENTES, A. F., BERTANI, T. M. \& MARDEGAN, R. 2015. Lean healthcare in developing countries: evidence from Brazilian hospitals. Int J Health Plann Manage.

DA CUNHA, A. M. C. A., DE CAMPOS, C. E.; RIFARACHI, H. H. C. 2011. Applicability of the Lean methodology in a hospital laundry. Mundo da Saude, 35, 311-318.

DA SILVA, I. B., SERAPHIM, E. C., AGOSTINHO, O. L., JUNIOR, O. F. L. \& BATALHA, G. F. 2015. Lean office in health organization in the Brazilian Army. International Journal of Lean Six Sigma, 6, 2-16.

EIRO, N. Y.; TORRES-JUNIOR, A. S. 2015. Comparative study: TQ and Lean Production ownership models in health services. Revista Latino-Americana de Enfermagem, 846854.
EROGLU, C.; HOFER, C. 2011. Lean, leaner, too lean? The inventory-performance link revisited. Journal of Operations Management, 29, 356-369.

FALAGAS, M. E., PITSOUNI, E. I., MALIETZIS, G. A. \& PAPPAS, G. 2008. Comparison of PubMed, Scopus, web of science, and Google scholar: strengths and weaknesses. The FASEB journal, 22, 338-342.

FEHOESP/IBPT 2016. Radiografia da saúde. Federação dos Hospitais, Clínicas e Laboratórios do Estado de São Paulo.

FERENHOF, H. A. F. R. F. 2016. Passos para construção da Revisão Sistemática e Bibliometria. V3.00 ed. IGCI.

FERRAZ, M. 1998. Health care trends in Brazil and other Latin American countries. Brazilian journal of medical and biological research, 31, 315-316.

FURUKAWA, P. D. O., CUNHA, I. C.; PEDREIRA, M. D. L. 2016. Evaluation of environmentally sustainable actions in the medication process. Rev Bras Enferm, 69, 16-22.

GODINHO FILHO, M., BOSCHI, A., RENTES, A. F., THURER, M.; BERTANI, T. M. 2015. Improving hospital performance by use of lean techniques: An action research project in Brazil. Quality Engineering, 27, 196-211.

GRABAN, M. 2011. Lean hospitals: Improving quality, patient safety, and employee engagement, CRC press.

HENRIQUE, D. B., RENTES, A. F., FILHO, M. G.; ESPOSTO, K. F. 2016. A new value stream mapping approach for healthcare environments. Production Planning and Control, 27, 24-48.

HOLWEG, M. 2007. The genealogy of lean production. Journal of Operations Management, 25, 420-437.

HORS, C., GOLDBERG, A. C., ALMEIDA, E. H., BABIO JUNIOR, F. G.; RIZZO, L. V. 2012. Application of the enterprise management tools Lean Six Sigma and PMBOK in developing a program of research management. Einstein (Sao Paulo), 10, 480-90.

LAURSEN, M. L., GERTSEN, F.; JOHANSEN, J. 2003. Applying lean thinking in hospitals-exploring implementation difficulties. Udgivet På: http://www.hctm.net/publications/ publications.html.

MAZZOCATO, P., SAVAGE, C., BROMMELS, M., ARONSSON, H.; THOR, J. 2010. Lean thinking in healthcare: a realist review of the literature. Quality \& Safety in Health Care, 19, 376-382.

MORAROS, J., LEMSTRA, M.; NWANKWO, C. 2016. Lean interventions in healthcare: Do they actually work? A systematic literature review. International Journal for Quality in Health Care, 28, 150-165. 
OHNO, T. 1988. Toyota production system: beyond largescale production, crc Press.

OKOLI, C.; SCHABRAM, K. 2010. A guide to conducting a systematic literature review of information systems research. Sprouts Work. Pap. Inf. Syst, 10, 26.

PAIM, J., TRAVASSOS, C., ALMEIDA, C., BAHIA, L.; MACINKO, J. 2011. The Brazilian health system: history, advances, and challenges. The Lancet, 377, 1778-1797.

PERALTA, C. B. D. L.; FORCELLINI, F. A. 2015. Lean Healthcare: uma análise da literatura. Produto \& Produção, 16, 93-113.

QUETZ, J. S., DANTAS, I. F., HIRTH, C. G., BRASIL, C. G.; JUAÇABA, S. F. 2015. Preliminary results of Lean method implementation in a pathology lab from Northeastern Brazil. Jornal Brasileiro de Patologia e Medicina Laboratorial, 33-38.

TOUSSAINT, J.; GERARD, R. 2010. On the mend: revolutionizing healthcare to save lives and transform the industry, Lean enterprise institute.

VEIGA, G. L., DE LIMA, E. P., ANGELIS, J. J.; DA COSTA, S. E. G. 2011. The Strategic role of lean-a discussion. Brazilian Journal of Operations \& Production Management, 8, 9-30.

WOMACK, J. P., BYRNE, A. P., FIUME, O. J., KAPLAN, G. S.; TOUSSAINT, J. 2005. Going lean in health care. Cambridge, MA: Institute for Healthcare Improvement.

WOMACK, J. P.; JONES, D. T. 1994. From lean production to lean enterprise. Harvard business review, 72, 93-103.

WOMACK, J. P., JONES, D. T.; ROOS, D. 1990. Machine that changed the world, Simon and Schuster.

YOUNG, T. P.; MCCLEAN, S. I. 2008. A critical look at Lean Thinking in healthcare. Quality and Safety in Health Care, 17, 382-386. 